TECHNICAL TRANSACTIONS 12/2017

CZASOPISMO TECHNICZNE 12/2017

\title{
ARCHITECTURE AND URBAN PLANNING
}

DOI: $10.4467 / 2353737$ XCT.17.206.7749

\author{
Magdalena Jagiełło-Kowalczyk (magdajagiellok@interia.pl) \\ Institute of Urban Design, Faculty of Architecture, Cracow University of Technology
}
Social, Economic, Spatial and Construction-related Problems of ZWIERZYNiec. The Four SEASONS

\section{PROBLEMY SPOEECZNE, GOSPODARCZE, PRZESTRZENNO-INWESTYCYJNE ZWIERZYŃCA. CZTERY PORY ROKU}

\begin{abstract}
The publication presents the social, economic, spatial and construction-related problems that are being faced by the commune of Zwierzyniec. It discusses the effects of the cooperation of the commune with the Faculty of Architecture of the Cracow University of Technology. These effects, expressed in the form of diploma engineer's design theses of the students of the Faculty of Architecture, are to promote Zwierzyniec and its activation during all of the seasons of the year. One of the important, identified problems of the area of Roztocze in question is that all activity "freezes" there during the autumn and winter seasons.
\end{abstract}

Keywords: Social, economic, spatial, construction-related problems, activation

\section{Streszczenie}

Publikacja przedstawia problemy społeczne, gospodarcze i przestrzenno-inwestycyjne, z jakimi boryka się gmina Zwierzyniec. Omawia efekty wspólpracy gminy z Wydziałem Architektury Politechniki Krakowskiej. Efekty te, wyrażone w postaci projektów dyplomowych inżynierskich studentów Wydziału Architektury, mają służyć promocji Zwierzyńca i jego aktywizacji we wszystkich porach roku. Jednym bowiem z istotnych, zidentyfikowanych problemów omawianego terenu Roztocza jest jego „zamieranie” w sezonie jesienno-zimowym.

Słowa kluczowe: Problemy społeczne, gospodarcze, przestrzenne, inwestycyjne, aktywizacja 


\section{Introduction}

The founding of Zwierzyniec is dated to the year 1593 [1]. It was then that a hunting bestiary was established at the site, surrounded by a 30-kilometre long fence, along with a manor made of larch. This gave the locality its name. At the beginning of the XIX century, the Zamoyski family relocated the Authority of the Zamoyski Family Fee Tail to Zwierzyniec. A complex of classicist halls that had been built for this purpose was to be its headquarters. This is also the time when the houses for the administrators of the fee tail were built. Foreign specialists from England, Italy and Germany were hired to work in the first agricultural equipment factory in Poland - built in the year 1804 - and the still functioning brewery from 1806. During the November Uprising Zwierzyniec was the site of the camping and movement of military forces, and the January Uprising has had one of its victorious battles in nearby Panasówka. In 1901 Józef Piłsudski, then a runaway from Petersburg, found help and shelter here. Thanks to the help of the fee tail's foresters, he made his way illegally across the border with Galicia on the Tanew River. During the turn of the XIX and XX centuries, Zwierzyniec became an attractive tourist resort. The fence of the hunting bestiary was completely dismantled in 1905 . In September 1939, Zwierzyniec found itself along the combat trail of Stefan Rowecki and Stanisław Sosabowski, while during the occupation, it was the site of a prospering centre of the $9^{\text {th }}$ infantry regiment of the Home Army Legions. The Nazi German prisoner of war camp for French captives was transformed into a transition camp for the pacified and forcefully relocated the population of the Zamojszczyzna. Ordinate Jan Zamoyski, along with his wife, involved themselves in the effort to save children from this camp. During the end of 1939, the supervision of the Zamoyski Family Fee Tail was taken over by the occupation authorities, with the Red Army entering this area in 1944. Even then, the 59,054-hectare fee tail was a large, well-organised manorial enterprise, bringing in quite a profit. On the $6^{\text {th }}$ of September 1944, by decree of the PKWN regarding agricultural reform, the 350-year-old Zamoyski Family Fee Tail was dissolved. Zwierzyniec gained town rights in 1990. This charming, forest town, often called the Pearl of Roztocze [2] combines natural and cultural qualities. The four centuries of Zwierzyniec's history were, fortunately for the town, dominated by the Zamoyski Family Fee Tail. It is thanks to the Fee Tail that the cultural development of these lands had not destroyed, but rather underlined the natural qualities that were assigned for protection by creating the Roztocze National Park in 1974. The wonderfully wild green areas, both natural and manmade water layouts are matched with the material traces of the past. In this field, Zwierzyniec can pride itself in its small Baroque church, built on one of the islands of the lake in the years 1741-1747 by Teresa and Tomasz Zomoyski in thanks for the birth of their long-awaited son, the historical buildings of the Zamoyski Family Fee Tail, the XIX century brewery or the exceptional district of small timber houses called Borek, which was built during the period of the interbellum. The town, simply breathing history, flowing through the beautiful landscape of Roztocze, is, however, facing numerous problems, most of which have been identified, but still wait to be solved. Can the cooperation with the Faculty of Architecture of the Cracow University of Technology help, if only partially, to achieve this goal? 


\section{Identifying the main problems of the commune of Zwierzyniec}

A series of main problems that affect the authorities and the inhabitants of the commune of Zwierzyniec has been identified [3]. The problems can be divided into three groups: problems that affect the social sphere, economic problems and spatial and constructionrelated problems (existing facilities, roads and technical infrastructure, public spaces, environmental and cultural problems).

In the social sphere, we can see the emergence of issues regarding the material wellbeing of inhabitants, shelter, security, healthcare, the life and care for disabled persons, personal development, access to culture, sports, recreation, social contacts, a feeling of identification with the town and the community, access to communication and information from the media and consumer needs, that require addressing and that decisions be made.

The problems associated with the material and residential wellbeing of inhabitants have been defined as follows: an insufficient amount of jobs for persons with a higher education, the low economic standing of a large part of the inhabitants, poor use of social economy instruments, the lack of the capability to provide shelter to persons and families in need and the occurrence of difficulties for the residents of multi-family residential buildings belonging to the Housing Cooperative that are rooted in the high energy demands of these buildings.

In regard to security, incidents of disrupting public peace and some felonies were identified, mainly during the tourist season. Excessive and disrupting transit traffic through the voivodship road that crosses the city, as well as on some of the crossings in Zwierzyniec, in addition to the noise and vibrations generated by the wide-track railway line, is a different kind of danger.

In terms of healthcare and the life and care for those in need, the necessity to carry out feeding programmes in preschools, schools and the cafeteria has been identified. Limited access to rehabilitation and the problem with the care for the rising number of disabled and senior persons that require specialist care is also making itself evident. This is associated with a larger number of persons who are unable to function in the job market.

The town has an insufficient offering in terms of spending one's free time, sports and recreation. The offering of the only cinema in Zwierzyniec has been found to be of low quality and scope due to ageing technical equipment. An unsatisfactory offering in terms of culture for both residents and tourists has been identified. This comes down to the conclusion that the potential of the locality in terms of creating a cultural, recreational and tourist offering is made use of in an insufficient manner. In the sphere of education, it has been determined that schools are inappropriately equipped with educational aids.

A series of problems exist in the sphere of social contacts, group ties and the feeling of identification with the town and the community. A low amount of involvement in local democracy mechanisms by the inhabitants is observable. Other elements that have been identified are: a low level of the integration of the residents of the community and passivity regarding participation in various cultural, economic and social events or initiatives, a low level of the residents' participation in the commune's management, a very small amount of persons willing to participate in voluntary work, the passivity of a part of those persons who 
receive social benefits in undertaking efforts that would improve their material situation, a low level of physical activity among the residents.

Regarding the ease of contact and access to information, the lack of coverage by mobile phone networks and Internet broadband service providers in some areas is a large problem, as well as the lack of optical fibre networks. This causes difficulties in communication and those associated with the lack of access to information.

In terms of consumer needs, a limited availability of basic services and an insufficient offer in terms of small gastronomy and a lack of a marketplace organised to a modern standard.

The key sectors that influence the economic development of the region are: the timber industry (woodcutting, furniture production, palette production), the forestry industry, tourism, food processing (brewery) and agriculture.

These fields have problems regarding the small scale of production and the seasonal nature of woodcutting. The following have been observed: a low competitive position of the Forestry Services Plant, the unregulated legal status of the buildings of the brewery, underdeveloped, fragmented, low-volume agriculture, the seasonal nature of the demand for gastronomy-type service. Tourism in the region has problems that have been identified as a lack of categorised tourist facilities, a lack of leading tourist facilities, a tourist season that is too short, a narrow, seasonal offering, a low number of foreign tourists, the lack of an integrated promotion of the community's offering in terms of tourism.

There are serious problems with the employment market. These include: the low mobility of the residents that generates unemployment, the incompatibility of the qualifications of the unemployed to the needs of the job market, the low activity of a part of the unemployed in the search for and taking up of employment, insufficient professional qualifications of a part of the persons who provide services in tourism.

One obstacle in the economic development of the community is the low amount of available buildable areas, a fragmentation of the ownership structure, an insufficient number of property developers, very limited opportunities in terms of attracting a large investor and the poor effects of the efforts of non-government organisations in this field, the low activity of non-government organisations in securing outside funding, a low level of cooperation between non-government organisations and commune authorities and between nongovernment organisations themselves.

In terms of existing facilities, we can observe problems such as: the high energy demand of the residential buildings of the Housing Cooperative, the lack of protected social housing, the insufficient facility base and technical equipment of the Cultural Centre and the Public Library in Zwierzyniec, village clubhouse buildings that require modernisation/ redevelopment, the poor technical condition of a part of the historical buildings.

The topic of roads and technical infrastructure is associated with: the lack of sewerage in a part of the locality, the necessity to construct a local waterworks network, the poor technical condition of some commune and powiat-grade roads, the partial lack of illumination, an insufficient amount of sidewalks, bike lanes and walkways, the necessity to modernise pedestrian and road bridges on commune roads, the necessity to build local roads in areas where the amount of buildings is rising, an insufficient amount of parking lots and parking spaces. 
There are architectural barriers for disabled persons in public spaces, an insufficient number of public toilets is observable, as well as a poorly developed tourist, sports and recreation infrastructure (few swimming spots, the lack of a swimming pool, etc.), in addition to the imperfection of the state of the architectural and natural development, chaotic built-up areas that negatively affect the landscape.

There are several environmental problems that appear in the area of the community of Zwierzyniec: illegal waste dumping sites, secondary succession in wastelands, the overgrowing of unused farmland, the lack of or an insufficiently developed sewerage system in some parts of the community and an outdated sewerage system in a part of Zwierzyniec, the negative influence of the wide-rail railway line that generates noise and vibrations, coal-powered boiler rooms, a waterworks network that partially requires modernisation, the lack of the technical means to process organic waste, a low degree of the use of renewable energy sources, dangers arising from intense, heavy transit traffic that goes through the centre of Zwierzyniec.

Cultural problems associated with construction include: the disappearance of culture and local customs; an insufficiently broad offering of cultural events; the degradation of a part of the historical buildings; legal limitations regarding care for historical buildings and unsolved property issues.

\section{Architecture - The Four Seasons}

Six engineer's diploma design theses were developed as a part of an agreement between the commune of Zwierzyniec and the Faculty of Architecture of the Cracow University of Technology [4]. The students visited Zwierzyniec in order to inspect the site in person and perform urban design analyses. During these visits, they had the opportunity to get to know the town in depth and get a feel for its atmosphere. They met with representatives of the commune office and the local community. They have also been presented with the problems that the commune is struggling with and that it needs to face. The students pointed out the low degree of industrialisation and urbanisation of Zwierzyniec and its focus on agriculture and forestry. They remarked that the town is alive mostly during the summer season, which is when cultural events are organised $[5,15,16]$ In terms of an offering for tourists, there are kayak trips, as well as the opportunity to experience the Eastern Poland Bike Trail which runs through here. During winter, however, the town becomes inactive. There is a lack of facilities that would activate the local community and strengthen the residents' feeling of identity, but that would also stimulate the inflow of tourists. Tourism can be seen as the source of the social and economic development of the region, which can improve the material wellbeing of its residents. Zwierzyniec owes its charm chiefly to its massive forestation and the beautiful natural landscape of the Roztocze National Park. However, many green areas are undeveloped and devastated. The students have performed circulation, waterway, greenery and historical building placement analyses. They have performed an evaluation of the assets of the town's fragments, drawn conclusions and developed design guidelines. In cooperation with the town authorities, it was decided that designs of service and residential buildings - that could 
facilitate an improvement of the town's image, make it more attractive and active throughout all the seasons of the year - would be developed for recommended plots. The entire project has thus been called "The Four Seasons".

The first design involves the construction of a summer amphitheatre for around 800 spectators and the redevelopment of its surroundings [6]. The site, with a total surface area of $1,07 \mathrm{ha}$, is located in the centre of Zwierzyniec, in the northern part of the water and palatial complex near Wachniewskiej Street and is adjacent to Lake II. It is a flat area free of buildings, in the southern part of which, near the water, there runs an embankment. The area is covered with low-lying littoral greenery. According to regulations in the Local Area Development Plan, all real estate development on this site requires the approval of the Voivodship Conservator of Historical Buildings [7]. This place is to become the town's main attraction, which would activate the local population and stimulate tourism. The concerts that would take place here during summer, as well as other music events, would have a proper and interesting place to be organised. The music would be heard from the spectator stands, but also from the opposite shore of the lake, or during a romantic boat ride on the water. The rich functional programme of the backrooms for the artists and spectators would also stimulate social contact in this area. A light, "winged" form was developed, which features a proposal of using a roof covering system made from ETFE air cushions. According to the author, the shaping of modern forms in a historical environment enriches the existing spatial and cultural context.

The topic of the second work is the building of a worker's hotel in Zwierzyniec, which also provides rooms for tourists to spend the night in [8]. The building is to be located on a site with a surface area of $2755 \mathrm{~m}^{2}$ in the western part of the town near Zdrowotna Street. A project located at this site requires the approval of the Voivodship Conservator of Historical Monuments [7]. The design features a building composed of two intertwining, mutually contrasting shapes. The modernist form of the entry section has been contrasted with the classic, two-storey building covered with a gabled roof. The footprint surface area is $598 \mathrm{~m}^{2}$, while the entire project includes a terrace that has been designed to the west, from which there is a view of the fields and forests of Roztocze. The main part of the hotel is covered by a timber, latticework cladding, which is offset from the wall and backlit, which is to provide the effect of lightness and the illusion of it being from a fairy tale, in reference to the charms of "Magical Roztocze" [9]. The hotel is adapted to being used by disabled persons. The technical solutions implemented in the building guarantee its energy efficiency, while "green" parking spaces on a comparably small plot provide the proper amount of biologically active area.

A harbour with accompanying infrastructure has been designed to bring order to the space near the western shore of the lake on the Wieprz River [10]. The plot on which the construction of a harbour has been planned is located on Rudka Lake in Zwierzyniec. Currently, it is the site of an earthen parking lot. During the summer, kayaks and water bikes are chaotically anchored near the shore of the lake. The design includes the construction of a new, functional structure with a regular shape. The building is oriented in parallel to the shoreline. The building's distinct quality are timber pillars which are displayed on the facade. They were meant as a reference to the tree trunks of the trees that grow in the Roztocze National Park. There is a multifunctional hall dedicated to events associated with this place in 
the main part of the building. There is a room for lifeguards, as well as a number of backrooms and technical rooms nearby. On the ground floor, there is a hall dedicated to the storage, repair and conservation of sailing equipment. The building has a glazed, double-skin facade. Thus, the rooms have an unblocked view of the lake and the natural surroundings of Roztocze. The facade is free from load-bearing walls. This is because of the adoption of a post-and-beam structure based on concrete pillars.

The next subject is the development of a conceptual design of a covered swimming pool with a recreational section, gastronomy section, technical and backroom section and a parking lot [11]. The swimming pool has been placed in Zwierzyniec, near Armii Krajowej Street. The site is not large, which results in limitations regarding the introduction of a larger area of greenery. This is compensated by the park which is located on the opposite side of the street. The swimming pool is to be generally accessible and adapted to the needs of disabled persons. The massing of the building is minimalistic, with numerous glazed elements, the largest of which are located near the pools. The people who are going to use the pool will be able to not only enjoy their swim, but also to look at the park through the transparent glass walls. Each facade is decorated by a latticework structure made from stainless steel which has a naturallike form. The main inspirations in the design of the decorative cladding of the building were the park, the forests and the entire natural landscape of Roztocze. During the day, the sun will be able to shine through between the "branches" of the facade inside the building, creating fantastic compositions of light and shadow, while during the night, the light from the interior will be able to travel outside of the building, bringing to mind clearance in the forest. The colours of the building were kept in the currently fashionable tones of grey, white and black. The structural skeleton is composed of reinforced concrete elements. A roof composed of glued laminated timber has been designed above the swimming pool hall. The transparent walls have a post-and-beam structure, while the glass is fitted using spider-type fastenings. The interplay of the facades which resemble branches or trunks of trees, as well as nests made by birds, provides a feeling of lightness and spices up the simple shape of the building. In the opinion of the author of the design, the swimming pool, with its geometric form and facades inspired by the nature of Zwierzyniec, is going to elevate the touristic qualities of this picturesque region even more, activating the town in the summer, spring, autumn and winter.

The design of covered ice skating rink features the construction of a building that would activate the population of the town - which is the most active during the summer- in the winter [12]. The site, with a total surface area of $4,54 \mathrm{ha}$, located in the centre of the town of Zwierzyniec contains within its borders the palace and park complex of the Zamoyski Family Fee Tail Authority. The part chosen for the project constitutes an undeveloped plot in the direct vicinity of Zwierzyńczyk [13]. The Local Spatial Development Plan designates this site with the symbol A70-IK, and all real estate development associated with it should be approved by Voivodship Conservator of Historical Buildings [7]. The design is also meant to be a tourist magnet, which would be an element that could drive the development of the region. The answer to this challenge came in the form of a design of an all-year ice skating rink. Its massing is inscribed into the surrounding landscape and its facade opens up towards the Zwierzyńczyk. The interior intertwines with the exterior, architecture mixes with nature. 
The user of the ice skating rink has a view of the water: as it forms waves in tune to the gusts of wind, cradled by greenery in the summer, and bound in ice in the winter. The massing, according to the author's concept, is to be in the shape of a chunk of ice. The building, apart from the ice skating rink hall and social and administrative rooms, also has a spectator area for around two hundred spectators. The structure of the building is based on a combination of reinforced concrete and glued laminated timber.

The last design is the multi-family residential building with services on the ground floor. [14] The site is located in Zwierzyniec in the vicinity of Jasna Street, on a narrow plot, the surroundings of which are made up of other multi-family buildings of a similar size. The access to all amenities is provided from the side of Jasna Street. According to the Local Area Development Plan [7], the site is assigned for the construction of a residential building. A fourstorey multi-family residential building with services on the ground floor has been designed. The proposed services include a fitness club, which would be very welcome here, as well as a hairdressing salon and a coffee shop. The three remaining stories contain apartments, which are divided into two types: small, single level ones with a surface area of around $70 \mathrm{~m}^{2}$ and larger, two-level ones with a surface area of around $130 \mathrm{~m}^{2}$. The apartments are functional, and the building, in accordance with the principles of sustainable design, is to be energy efficient, which is going to be beneficial to the wallets of the residents. The form of the building, as well as its facades, were inspired by local timber architecture, as well as the neighbouring surroundings. In order to achieve a greater lightness of form, the massing was divided into smaller parts using glazed staircases. The colours black and white were used, while the roof was "rotated" in order to give the building a more modern, dynamic appearance.

\section{CONCLUSION}

The entire region of Roztocze is a true landscape jewel of Poland, one that has not been fully discovered yet. We can calm down here, experience nature and simply find rest. Zwierzyniec is a charming town that blends into the nature of this area. It awakens during spring, lives over the summer, falls asleep during autumn and freezes during winter. To a visitor who seeks peace, an escape from the hustle and bustle of the cities, from the problems and frantic pace of life, the town's stagnation and lethargy are oftentimes seen as its advantage. However, the people who visit this town for longer, for touristic reasons, quickly begin to search for entertainment and propositions of active recreation. In the summer, these requirements are seemingly met, however, the tourist offering can be made more attractive for this time as well, in order to adapt it to a larger number of consumers and, first and foremost, propagate it. Autumn, winter, even spring in Zwierzyniec await an awakening. The influx of tourists and the activation of the residents themselves would undoubtedly influence the economic development of the town. New jobs would be adapted to all of the year's seasons. An improvement in the living conditions of residents, as well as their identification with the image of an attractive tourist town, should also prevent the outflow of people in search of work. The authorities of Zwierzyniec, when identifying its problems, underlined the necessity 
to activate the region. Cooperation with the Faculty of Architecture of the Cracow University of Technology is based on preparing an offer for the town under the common title "The Four Seasons". Their construction would, without a doubt, lead to a revival of Zwierzyniec. For now, however, the students' designs can serve as an element of the promotion of the town.

\section{References}

[1] http://www.zwierzyniec.info.pl (access: 17.03.2017).

[2] www.magicznyzwierzyniec.pl (access: 18.03.2017).

[3] www.inwestycje.zwierzyniec.vipserv.org/strategia/prob.pdf (access: 18.03.2017).

[4] Agreement no. A-0/46/2016 of 15 th of December 2016 regarding the coop-eration of the Town and Commune of Zwierzyniec, represented by Com-mune Mayor Jan Skiba, with the Thaddeus Kościuszko Cracow University of Technology, represented by the Dean of the Faculty of Architecture prof. Jacek Gyurkovich.

[5] Summer Film Academy http://laf.net.pl (access: 18.03.2017) http://www.kulturazwierzyniec.pl/rockowisko-2016 (access: 18.03.2017).

[6] Diploma design thesis author: Joanna Skoczeń, promotor: prof. Magdalena JagiełłoKowalczyk, auxiliary promotor: D.Sc. Ph.D. Bogdan Siedlecki, Krakow 2017

[7] Local Area Spatial Development Plan, http://www.zwierzyniec.info.pl (access: 29.03.2017).

[8] Diploma design thesis author: Marcin Musiałek, promotor: prof. Magdalena JagiełłoKowalczyk, auxiliary promotor: D.Sc. Ph.D. Jarosław Huebner, Kraków 2017.

[9] http://www.magiczneroztocze.pl (access: 29.03.2017).

[10] Diploma design thesis author: Monika Kraus, promotor: prof. Magdalena JagiełłoKowalczyk, auxiliary promotor: D.Sc. Ph.D. Bogdan Siedlecki, Krakow 2017.

[11] Diploma design thesis author: Magdalena Sendor, promotor: prof. Magdalena JagiełłoKowalczyk, auxiliary promotor: D.Sc. Ph.D. Przemysław Markiewicz, Krakow 2017.

[12] Diploma design thesis author: Konrad Piwowar, promotor: prof. Magdalena JagiełłoKowalczyk, auxiliary promotor: D.Sc. Ph.D. Bogdan Siedlecki, Krakow 2017.

[13] Zwierzyńczyk was established as a part of the project titled Odtworzenie zabytkowego układu wodno-pałacowego $w$ Zwierzyńcu wraz z zagospodarowaniem turystycznym, RPO Województwa Lubelskiego na lata 2007-2013, Oś Priorytetowa VII: Kultura, turystyka i współpraca międzyregionalna, http://www.magiczneroztocze.pl (access: 29.03.2017).

[14] Diploma design thesis author: Małgorzata Kozela, promotor: prof. Jagiełło-Kowalczyk, auxiliary promotor: D.Sc. Ph.D. Przemysław Markiewicz, Kraków 2017.

[15] http://www.kultura-zwierzyniec.pl/kategoria/warsztaty-wokalne (access: 18.03.2017).

[16] https://zwierzyniec.e-biuletyn.pl/upload/pliki/Ouchwala223.pdf (access: 18.03.2017). 